\title{
Biomasa łąk łęgowych jako integrator polityki energetycznej, przestrzennej oraz wodnej
}

\author{
Krzysztof Kud*
}

Wśród różnych rodzajów biomasy energetycznej na szczególna uwage zastuguje siano, ze względu na możliwość jego pozyskiwania z terenów nadrzecznych. W celu wtaściwego zagospodarowania terenów tęgowych konieczne jest prowadzenie tam racjonalnej polityki przestrzennej oraz wdrożenia systemu wsparcia produkcji OZE, zapewniajacej bezpieczeństwo wodne. Badania przeprowadzono na terenie dolin Sanu oraz Wistoka. Rolnicy gospodarujacy na terenach zalewowych nie uwzględniali produkcji siana na cele energetyczne. Systemowe rozwiazanie, wspierające pozyskiwanie z terenów zalewowych siana na cele energetyczne, przyniosłoby korzyści w postaci poprawy miksu energetycznego, bezpieczeństwa wodnego, lepszego wykorzystania procesu aluwialnego oraz uniknięcia strat powodziowych.

Słowa kluczowe: OZE, biomasa siana, tereny zalewowe, bezpieczeństwo, wsparcie systemowe.

Nadesłany: 04.07.18 | Zaakceptowany do druku: 11.12.18

\section{Biomass of riparian meadows as an integrator of energy policy, spatial and water}

Among the various types of energy biomass, hay deserves particular attention because of the possibility of obtaining it from riverside areas that perform a number of different functions. In order to properly manage flood plains, it is necessary to conduct a rational spatial policy there and a support system for RES production ensuring water safety. The research was carried out in the valleys of San and Wistok rivers. Farmers farming on floodplains did not include hay production for energy purposes. System solutions supporting the acquisition of floodplain hay for energy purposes, would benefit in terms of improved energy mix, water security, better use of the process and avoid the alluvial flood losses.

Keywords: renewable energy, hay biomass, floodplains, security, system support.

Submitted: 04.07.18 | Accepted: 11.12.18

JEL: Q2, Q5, Q28, Q40, P32

\footnotetext{
Krzysztof Kud - dr hab. inż., prof. PRz, Politechnika Rzeszowska, Wydział Zarządzania. Adres do korespondencji: Politechnika Rzeszowska, Wydział Zarządzania, Katedra Przedsiębiorczości, Zarządzania i Ekoinnowacyjności, al. Powstańców Warszawy 8, 35-959 Rzeszów, e-mail: kkud@prz. edu.pl.
} 


\section{Wprowadzenie}

Rosnące potrzeby energetyczne współczesnej gospodarki, znaczenie energii jako czynnika bezpieczeństwa państwa oraz wyczerpywanie kopalnych źródeł energii, wymagają interdyscyplinarnego podejścia do zagadnienia bezpieczeństwa energetycznego. Wzrost zainteresowania odnawialnymi źródłami energii sprowadza się już nie tylko do rachunku ekonomicznego oraz (ewentualnie) emisji gazów cieplarnianych, ale ma również wymiar społeczny, w tym kulturowy i estetyczny. Pozyskiwanie energii z biomasy wiąże się $\mathrm{z}$ wieloma kontrowersjami zarówno technicznymi, podczas jej spalania, jak i wynikającymi z jej produkcji, np. zanikiem bioróżnorodności, negatywnym wpływem na jakość gleb, stosunki wodne oraz związanymi z aspektami społecznymi, zmianami w strukturze produkcji i cen żywności.

Na szczególną uwagę wśród roślin energetycznych zasługuje biomasa pozyskiwana z trwałych użytków zielonych (TUZ) zlokalizowanych na terenach zalewowych. Niewielkie koszty pozyskiwania, wartość energetyczna oraz szereg istotnych funkcji środowiskowych i gospodarczych, pełnionych przez łąki zalewowe sprawiają, że uprawy tego typu powinny stanowić istotny element $\mathrm{w}$ systemie zagospodarowania terenów nadrzecznych. W niniejszej pracy przedstawiono wyniki badań przeprowadzonych w dolinach Sanu oraz Wisłoka.

Celem artykułu jest przedstawienie funkcji naturalnych łąk łęgowych w zapewnianiu bezpieczeństwa wodnego oraz możliwości energetycznego wykorzystania biomasy pozyskiwanej z nich, jak również konieczności zapewnienia właściwej ochrony tych obszarów w polityce przestrzennej. Kluczowym zagadnieniem staje się stworzenie warunków zachęcających rolników do rozwijania uprawy trwałych użytków zielonych na terenach zalewowych. Przeprowadzone badania miały na celu diagnozę możliwości zmiany zagospodarowania terenów zalewowych zgodnie $\mathrm{z}$ postulatem nowoczesnej strategii zapewniania bezpieczeństwa, polegającej na pozostawianiu rzekom przestrzeni.

Badania przeprowadzono w 2015 roku na terenie doliny Sanu i w 2016 roku w dolinie rzeki Wisłok. Metodą badawczą był ustrukturyzowany wywiad pogłębiony przeprowadzany $\mathrm{z}$ właścicielami gospodarstw rolnych. Dobór próby był celowy; wybrano gospodarstwa, których część areału podlegała cyklicznemu podtapianiu i zalewom powodziowym. W dolinie Sanu przeprowadzono 199 wywiadów, zaś w dolinie Wisłoka 91. Główne zagadnienia badawcze obejmowały postrzeganie przez rolników następczego oddziaływania podtopień i zalewów powodziowych, oczekiwań względem lokalnych władz odnośnie pomocy i niwelowania negatywnych skutków powodzi i suszy oraz skłonności do zmiany sposobu użytkowania terenów zagrożonych. W efekcie przeprowadzonych analiz sformułowano wnioski o charakterze rekomendacji, mogące wywołać pożądane zmiany w gospodarce.

\section{Determinanty gospodarki na terenach zalewowych}

\section{Zmiany klimatyczne}

Obserwowane od pewnego czasu zmiany klimatyczne stanowią poważne wyzwanie dla współczesnej gospodarki (Alaerts, 2019). Istotna część działalności człowieka pozostaje w ścisłym związku ze stanem środowiska naturalnego i w znacznej mierze jest wystawiona na niszczycielski wpływ czynników naturalnych. Zwłaszcza sektor rolniczy, dostarczający żywności i niektórych surowców, jest uzależniony od zjawisk pogodowych.

Wzrastająca częstotliwość występowania ekstremalnych zjawisk pogodowych (w tym powodzi i susz), zmiany terminów faz fizjologicznych roślin, terenów i form aktywności fauny, granic występowania gatunków zarówno w układzie równoleżnikowym, jak też poziomicowym, łączone są ze wzrastającą globalną temperaturą (Kundzewicz, 2011; Alaerts, 2019). Zmiany klimatyczne niosą ze sobą różnorakie zagrożenia w naturalnych ekosystemach i ich różnorodności biologicznej, wywołuja spowolnienie wzrostu gospodarczego, utrudniają zachowanie bezpieczeństwa żywnościowego na świecie, powoduja zagrożenie dla człowieka, jego zdrowia, powodują wzrost nierówności społecznych. Wiążą się również z daleko idącymi zmianami w reżimie opadów atmosferycznych, co w efekcie skutkuje zmianami w zasobach wodnych Ziemi (Lorenc, 2012).

Komisja Europejska dostrzega problem niedoboru wody i podejmuje działania mające na celu likwidację skutków susz. O ile opracowuje się jednak wskaźniki do 
szacowania zagrożenia tym zjawiskiem, ustala ceny wody, stosuje rozdzielniki i ewidencję poboru, o tyle niewiele poprawiono w obszarze zwiększania retencji. „Zmiany sposobu użytkowania gruntów w celu zmniejszenia wrażliwości zasobów wodnych nie są powszechne na poziomie państw członkowskich, a zamiast zintegrowanego gospodarowania gruntami i zasobami wodnymi promowane są bardzo rozproszone działania wspierające i środki techniczne." (COM, 2012) Stąd zachodzi konieczność przeciwdziałania tym niekorzystnym zjawiskom, a jedną ze skutecznych metod jest zwiększanie małej retencji wody.

\section{Specyfika i wielofunkcyjność terenów zalewowych}

Doliny rzek są kształtowane przez płynącą wodę i podlegają ciaggłym przemianom. Obszary bezpośrednio sąsiadujące z korytem rzeki, na których występują podtopienia i wylewy powodziowe, nazywane są terenami łęgowymi (terenami zalewowymi). Wykształcają się tam specyficzne ekosystemy odporne na okresowe zalewanie wodami powodziowymi. Gatunki roślin i zwierząt nieznoszące takich warunków zostają wyeliminowane, natomiast wytwarza się biocenoza tolerująca okresowe zalewanie. Gleby w dolinach rzek zazwyczaj powstają na skutek erozyjno-sedymentacyjnej działalności wód powierzchniowych. Po zalewach powodziowych na powierzchni gleb pozostaje cienka warstwa namułu. W zależności od charakterystyki zlewni namuły te sa zasobne $\mathrm{w}$ pierwiastki biogenne, węgiel organiczny, węglan wapnia itp. Dzięki temu profile gleb aluwialnych są stale odmładzane i wzbogacane w biogeny zawarte w namułach (Kud, 2013). Deponowane w ten sposób namuły mają także znaczenie ekonomiczne, gdyż depozyt biogenów pełni funkcje nawozowe i daje się oszacować w kontekście finansowym (Woźniak i Kud, 2006).

Specyfika terenów łęgowych polega między innymi na tym, że stanowią obszary chętnie zabudowywane. Niestety dotychczasowe doświadczenia wskazują, że zabudowa techniczna terenów zalewowych przysparza znacznych i różnorakich strat. Wody powodziowe, zgodnie $\mathrm{z}$ dotychczas realizowaną strategią zapewniania bezpieczeństwa, utrzymywane w korycie i wąskiej przestrzeni międzywala, przy większych wezbraniach rozlewają się poza wały powodując znaczne szkody ekonomiczne. Ponadto techniczne zabezpieczenia przeciwpowodziowe są kosztowne, a w ostatecznym rozrachunku ich działanie jest nieskuteczne. Kolejne powodzie wymagają nakładów na likwidację szkód oraz rekonstrukcję zabezpieczeń. W ten sposób powstaje błędne koło zabezpieczeń przeciwpowodziowych (Twaróg, 2014; Lechowska, 2017). Współcześnie realizowana na świecie strategia pozostawiania rzekom przestrzeni znacznie bardziej chroni tereny nadrzeczne dzięki wykorzystaniu terenów łęgowych w celu spowolnienia (rozciągnięcia w czasie) spływu wód, obniżeniu fali kulminacyjnej, zmniejszeniu jej niszczycielskiego potencjału oraz wykorzystaniu użyźniającego depozytu aluwiów (González del Tánago, García de Jalón i Román, 2012; Kud i Kud, 2012; Schuch i in., 2017).

Naturalne łąki łęgowe pełnią również istotną funkcję retencyjną. Występowanie wody $z$ koryta rzeki i rozlewanie się na tereny łęgowe zmniejsza prędkość przepływu oraz zwiększa retencję (Bańkowska $\mathrm{i}$ in., 2010), a jest to kluczowy czynnik w zapewnianiu bezpieczeństwa wodnego (Kud, 2016). Ważną funkcją łąk łęgowych jest zatrzymywanie przez nie depozytu biogenów, a także zanieczyszczeń ze spływu powierzchniowego. Ekstensywnie użytkowane łąki zalewowe pełnią funkcję ekotonów (buforów), stanowiąc pasy stałej roślinności pomiędzy rzeką a gruntami ornymi, zapobiegając eutrofizacji wód (Kud, 2013; Izydorczyk i in., 2015). Jednocześnie łąki łęgowe stanowią niezwykle cenne skupiska bioróżnorodności i jako takie wymagają specjalnego, ekstensywnego użytkowania w celu zachowania ich istotnego, przyrodniczego charakteru (Heinsoo i in., 2010).

Ekstensywnie użytkowane naturalne łąki zalewowe w tani sposób dostarczają cennej biomasy, która może mieć zastosowanie zarówno paszowe, jak i energetyczne. Jednocześnie są cennymi skupiskami bioróżnorodności o wysokich walorach krajobrazowych oraz stanowią kluczowy element systemu zapewniania bezpieczeństwa wodnego.

\section{Biomasa ląkowa w zastosowaniach energetycznych}

Spośród różnych rodzajów biomasy w tym opracowaniu szczególną uwagę zwrócono na pozyskiwaną z ekstensywnie 
użytkowanych łąk łęgowych. Na rysunku 1 przedstawiono wartość energetyczną siana w porównaniu ze słomą oraz innymi przykładowymi paliwami. Wartość energetyczna siana podczas spalania zbliżona jest do wartości słomy i nieco mniejsza od drewna. W zależności od formy przygotowania biomasy siana najwyższą kalorycznością charakteryzuje się pelet.

Badania przeprowadzone w Estonii (Melts i in., 2013) wykazały, że wartość energetyczna biomasy z półnaturalnych łąk zależy od rodzaju zbiorowisk roślinnych i metody konwersji energii. Dla biomasy z łąk aluwialnych wartość energetyczna siana wynosiła średnio $18,4 \mathrm{~kJ}^{-1}$, przy przeciętnych plonach $5,5 \mathrm{t} \mathrm{ha}^{-1}$, potencjał energetyczny wynosił 102,53 GJ ha-1 rok $^{-1}$. W przypadku produkcji biogazu potencjał łąk aluwialnych wynosił 55 GJ ha-1. $\mathrm{W}$ badaniach autora w dolinie Sanu (Kud, 2013) plon siana pierwszego odrostu wynosił przeciętnie nieco ponad $4 \mathrm{t} \mathrm{ha}^{-1}$, zatem stosując analogię, potencjał energetyczny wynosił około 74 GJ ha-1. Warto podkreślić, że były to łąki naturalne, nienawożone, zatem, mimo że potencjał energetyczny był nieco niższy od stwierdzonego w Estonii, to uzyskiwany był praktycznie bez ponoszenia kosztów.

Rysunek 1. Wartość energetyczna siana na tle innych paliw

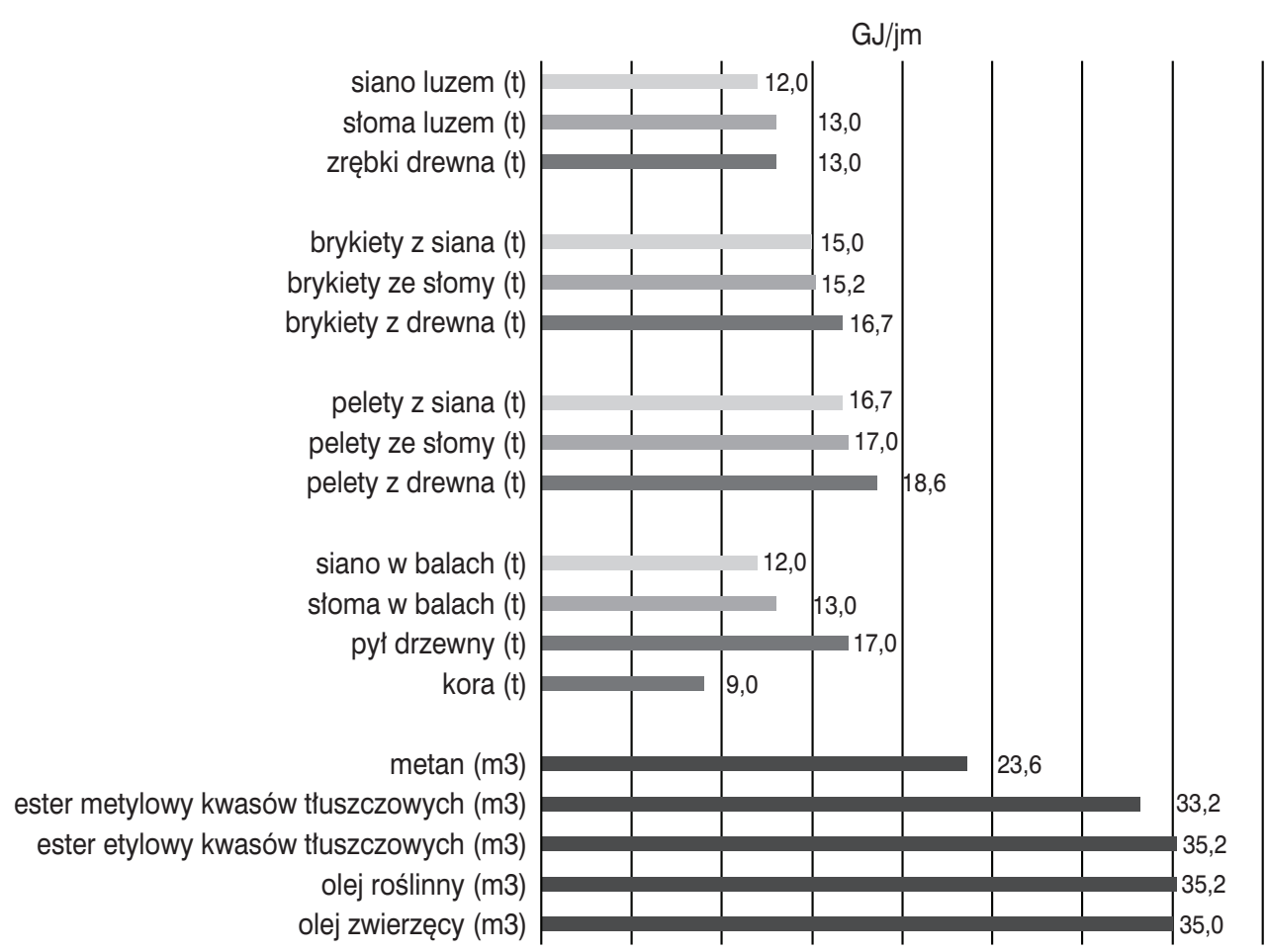

Źródło: opracowanie na podstawie: Malinowska, E., Wiśniewska-Kadżajan, B., Jankowski, K., Sosnowski, J. i Wyrębek H. (2014) Ocena przydatności biomasy różnych roślin na cele energetyczne, Zeszyty Naukowe UPH w Siedlcach, Nr 102 Ser. Administracja i Zarządzanie, s. 57.

Skład chemiczny biomasy trawiastej może być bardzo zmienny, w zależności od gatunku flory, żyzności gleby, nawożenia i pratotechniki. Stwarza to pewne trudności we właściwym spalaniu takiego paliwa. Najważniejsze cechy składowe niezbędne do oceny jakości peletu $\mathrm{z}$ trawy obejmują zawartość Cl, K, N, Si i S, popiół całkowity, zawartość wilgoci i wartość energii brutto. Zachodzi zatem potrzeba kontroli jakości peletów z roślin zielnych w celu uniknięcia nadmiernej emisji zanieczyszczeń (Cherney i Verma, 2013). Z drugiej strony, chwasty mogą znaleźć zastosowanie energetyczne nawet bez specjalnego przystosowywania pieca do ich spalania (Ciesielczuk i in., 2016). Otwiera to możliwości użytkowania gruntów marginalnych i odłogowanych. 


\section{4. Łąki łęgowe jako realizacja dobra publicznego}

Zagospodarowanie terenów zalewowych jest efektem działań planistycznych na szczeblu gmin. Tereny te stanowia warsztat pracy rolników tam gospodarujących, ale jednocześnie naturalne łąki zalewowe mają charakter przedsięwzięć łagodzących negatywne skutki zmian klimatycznych i jako takie wymagają specjalnego potraktowania.

W planach zagospodarowania przestrzennego tereny łęgowe powinny być możliwie najszerzej wyłączone z zabudowy, zaś działania przeciwpowodziowe polegające na regulacji rzek i potoków powinny zostać uznane za szkodliwe. Przeciwieństwem regulacji jest renaturyzacja. Wśród działań mających przywrócić uregulowanym rzekom stan zbliżony do naturalnego, prowadzi się przede wszystkim takie, które mają odwrócić zmiany hydrologiczne wprowadzone przez regulację, oraz takie, jak ulepszanie roślinności łęgowej, usuwanie jazów i przejść dla ryb itp. Sytuacja ta niesie ze sobą potrzebę zintegrowania polityki zagospodarowania przestrzennego i rozwoju obszarów wiejskich z zasobami wodnymi i gospodarką wodną oraz wskazuje na dodatkowe trudności w osiagnnięciu celów RDW i dobrego stanu ekologicznego rzek (González del Tánago i in., 2012).

Ze względu na liczne usługi, jakie pełnią tereny łęgowe, należy rozważyć rozwinięcie mechanizmu systemowego wsparcia zagospodarowania tych obszarów zgodnie $\mathrm{z}$ ich naturalnym potencjałem. W kontekście zmian klimatycznych zielona infrastruktura, jaką tworzą naturalne łąki aluwialne, skłania do uwzględnienia ich funkcji w decyzjach o użytkowaniu gruntów (Watson i in., 2016). Istotne znaczenie w systemie zapewniania bezpieczeństwa ma społeczeństwo. Obywatele - przez partycypację w obserwatoriach społecznych - dostarczaja bieżacej i aktualnej informacji o przebiegu zjawisk kryzysowych (Wehn, Rusca i Evers, 2015). Jednocześnie warto podkreślić, że zachodzące zmiany w ekosystemach mogą wymusić na rolnikach poszukiwanie alternatyw do tradycyjnych form i systemów gospodarowania (Chapman i in., 2017). Włączenie lokalnych przedsiębiorców rolnych do systemu zapewniającego powszechne korzyści może zostać zatem potraktowane jak realizacja dobra publicznego.
Westhoek, Overmars i van Zeijts (2013) wskazują, że wytwarzanie przez rolników dóbr rynkowych oraz publicznych jest poglądem szeroko akceptowanym. Problematyczny staje się niekiedy niższy poziom wytwarzania dóbr publicznych od zapotrzebowania społecznego. Jeżeli zachodzi obawa o przyszły poziom dostarczanych usług publicznych, to w pierwszej kolejności podejmowane są działania podnoszące poziom świadomości rolników. To jednak bywa niewystarczające i wówczas konieczna staje się interwencja państwa. Z badań autora wynika, że taka sytuacja zachodzi w przypadku utrzymywania naturalnych łąk łęgowych pełniących funkcje retencyjne, łagodzących negatywne skutki zmian klimatu (Kud, 2017).

\section{Badania w dolinach Sanu i Wisłoka}

Zagospodarowanie terenów łęgowych umożliwiające czerpanie korzyści ekonomicznych oraz wykorzystanie ich naturalnego potencjału niwelowania konsekwencji zmian klimatycznych wymaga przekształceń w strukturze użytkowania tych obszarów (Kud, 2016; 2017). Istotną rolę $\mathrm{w}$ wykorzystaniu potencjału łęgów odgrywa świadomość rolników, będących bezpośrednimi beneficjentami usług ekosystemowych świadczonych przez te specyficzne siedliska. Ze względu na fakt, że w procesie aluwialnym rzeka pozostawia depozyt namułów zasobnych w pierwiastki biogeniczne, dla wspomnianych przekszta1ceń zbadano poziom postrzegania korzyści wynikających z namulania. Na rysunku 2 przedstawiono strukturę ocen następczego wpływu powodzi na plony roślin polowych, zaś na rysunku 3 - na plony trwałych użytków zielonych.

Respondenci w obu badanych obszarach podobnie postrzegali oddziaływanie powodzi na plonowanie roślin uprawnych. Zdecydowana większość dostrzegała wysoki spadek plonów na gruntach ornych. W obu dolinach około $80 \%$ rolników dostrzegało mniejszy lub większy spadek plonów, jedynie 5,5\% badanych w dolinie Sanu i 7,7\% w dolinie Wisłoka dostrzegało pozytywny, następczy wpływ podtopień. W prowadzonych wywiadach podkreślano, że nie chodzi o wpływ w roku wystapienia zjawiska, ale o jego następcze konsekwencje. Rolnicy dostrzegali dużą żyzność terenów zalewo- 
wych, wskazywali na brak konieczności ich wapnowania, jednak nie łączyli bezpośrednio tego faktu $\mathrm{z}$ występowaniem powodzi.

Nieco inaczej przedstawiała się percepcja konsekwencji powodzi na terenie łąk zalewowych. Należy nadmienić, że nie wszyscy rolnicy posiadali trwałe użytki zielone na terenach łęgowych, jednak mimo tego wszystkich poproszono o wyrażenie opinii. W dolinie Sanu blisko 1/4, a w dolinie Wisłoka prawie $1 / 5$ badanych nie potrafiła określić następczego wpływu powodzi na plony łąk trwałych. W obu lokalizacjach niespełna połowa dostrzegała spadki plonów, a około 30\% wskazywało wzrost (rysunek 3). Nieco większy odsetek osób dostrzegających wzrost plonów łąk zalewowych odnotowano w dolinie Sanu.

Rysunek 2. Przekonanie badanych rolników odnośnie następczego oddziaływania powodzi na plony roślin polowych

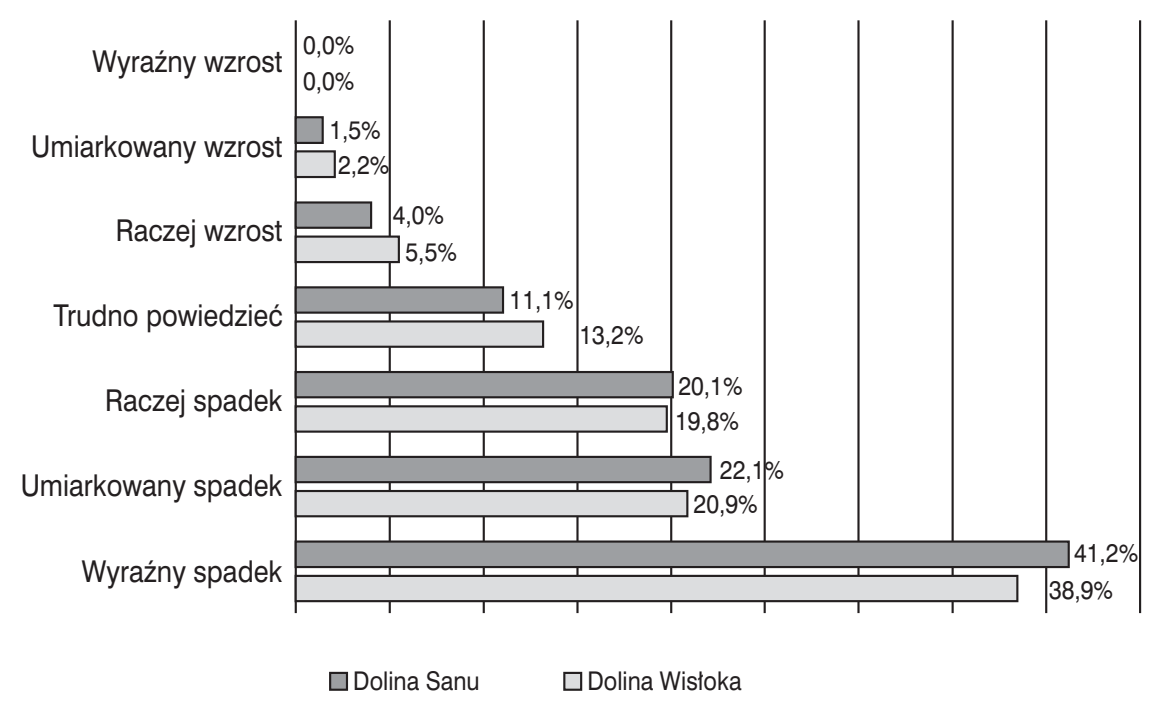

Rysunek 3. Przekonanie badanych rolników odnośnie następczego oddziaływania powodzi na plony naturalnych łąk zalewowych

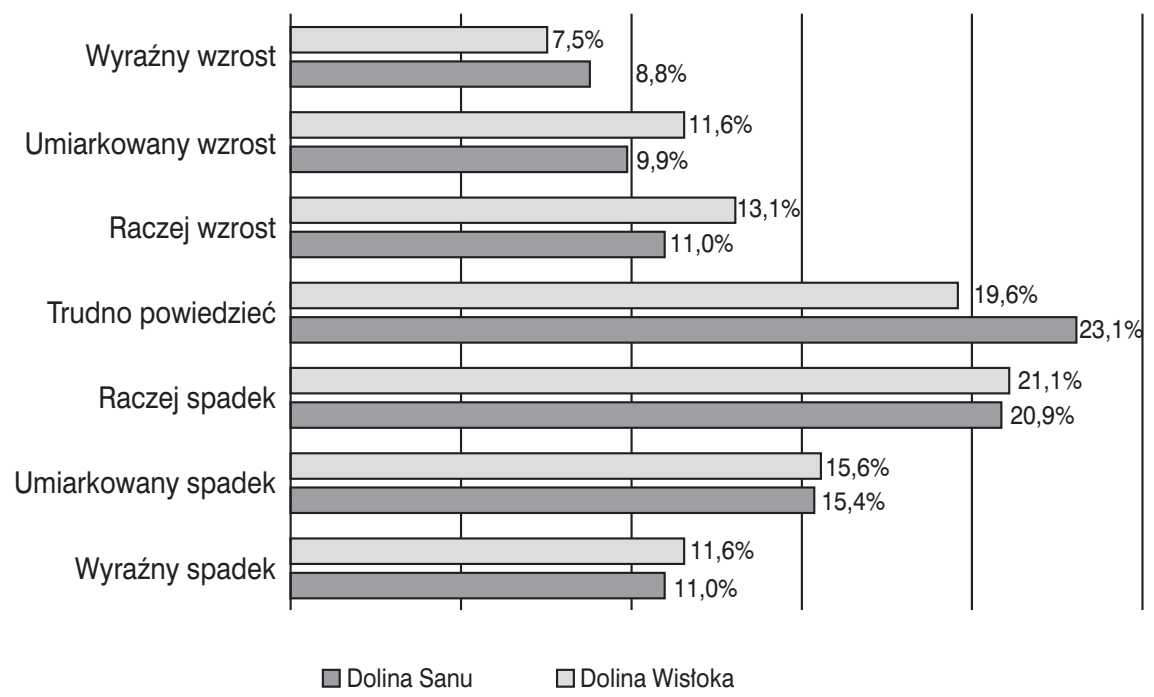

Przeprowadzone badania wskazywały na fakt, że rolnicy nie dostrzegali użyźniającego wpływu procesu aluwialnego. Rozwinięta była świadomość zagrożeń wynikających z zalewania upraw polowych, ale percepcja korzyści, zwłaszcza na łąkach łęgowych, była znikoma.

W celu włączenia terenów zalewowych w system zapewniający bezpieczeństwo wodne, konieczne wydaje się podniesienie 
świadomości rolników odnośnie do korzyści wynikających z użyźniającego wpływu procesu namulania. Dostateczna ilość wody stanowi kluczowy czynnik zapewniania wysokich plonów w rolnictwie (Islam i Managi, 2018). W projektowanej polityce wodnej ${ }^{1}$ wskazuje się na problemy nadmiernego przekształcania naturalnych warunków hydrologicznych wód powierzchniowych oraz podkreśla się konieczność ograniczania zabudowy terenów zalewowych, zachowania retencji i ograniczenia szybkości spływu wód. Wszystkie te postulaty realizuje uprawa naturalnych łąk zalewowych.

Zgodnie z Ustawą o planowaniu i zagospodarowaniu przestrzennym (2017) tereny zalewowe w lokalnych planach zagospodarowania przestrzennego powinny być wyłączone z zabudowy. Jednak, jak podaje NIK (2017, s. 17): „Niskie zaangażowanie gmin $\mathrm{w}$ prace związane $\mathrm{z}$ aktualizacją studium uwarunkowań i kierunków zagospodarowania przestrzennego miało negatywny wpływ na zapewnienie bezpieczeństwa dla inwestycji na terenach zagrożonych powodzią". Brak planów zagospodarowania przestrzennego uniemożliwia właściwe kształtowanie mechanizmów wsparcia na terenach zalewowych gospodarki zwiększającej bezpieczeństwo powodziowe.

Innym, ekstremalnym zjawiskiem pogodowym, jakiemu poświęcono uwagę w badaniach, była susza. Na rysunku 4 przedstawiono strukturę oczekiwań rolników, jeżeli chodzi o pomoc udzielaną im przez władze samorządowe. Z przedstawionych danych wynika, że ponad połowa rolników, w obu badanych obszarach, liczy na pomoc w nawadnianiu upraw. Próbowano dociec, jak rolnicy wyobrażają sobie takie działania. Odpowiedzi były bardzo zróżnicowane: od dowozu wody beczkowozami, po budowę rozwiniętych systemów nawadniających. Warto podkreślić niewielki odsetek osób dostrzegających konieczność zmniejszenia odpływu wody. Zagadnienie zwiększenia retencji postulowało zaledwie $5,3 \%$ rolników w dolinie Sanu oraz 6,8\% w dolinie Wisłoka. Jednocześnie podobny odsetek badanych $(7 \%$ w dolinie Sanu i 5,1\% w dolinie Wisłoka) oczekiwał działań regulacyjnych rzek, a te w rzeczywistości nie rozwiązują problemu powodzi i suszy, co potwierdzają badania np. González del Tánago i in. (2012).

Rysunek 4. Oczekiwania badanych rolników odnośnie do pomocy ze strony władz lokalnych w celu łagodzenia skutków suszy

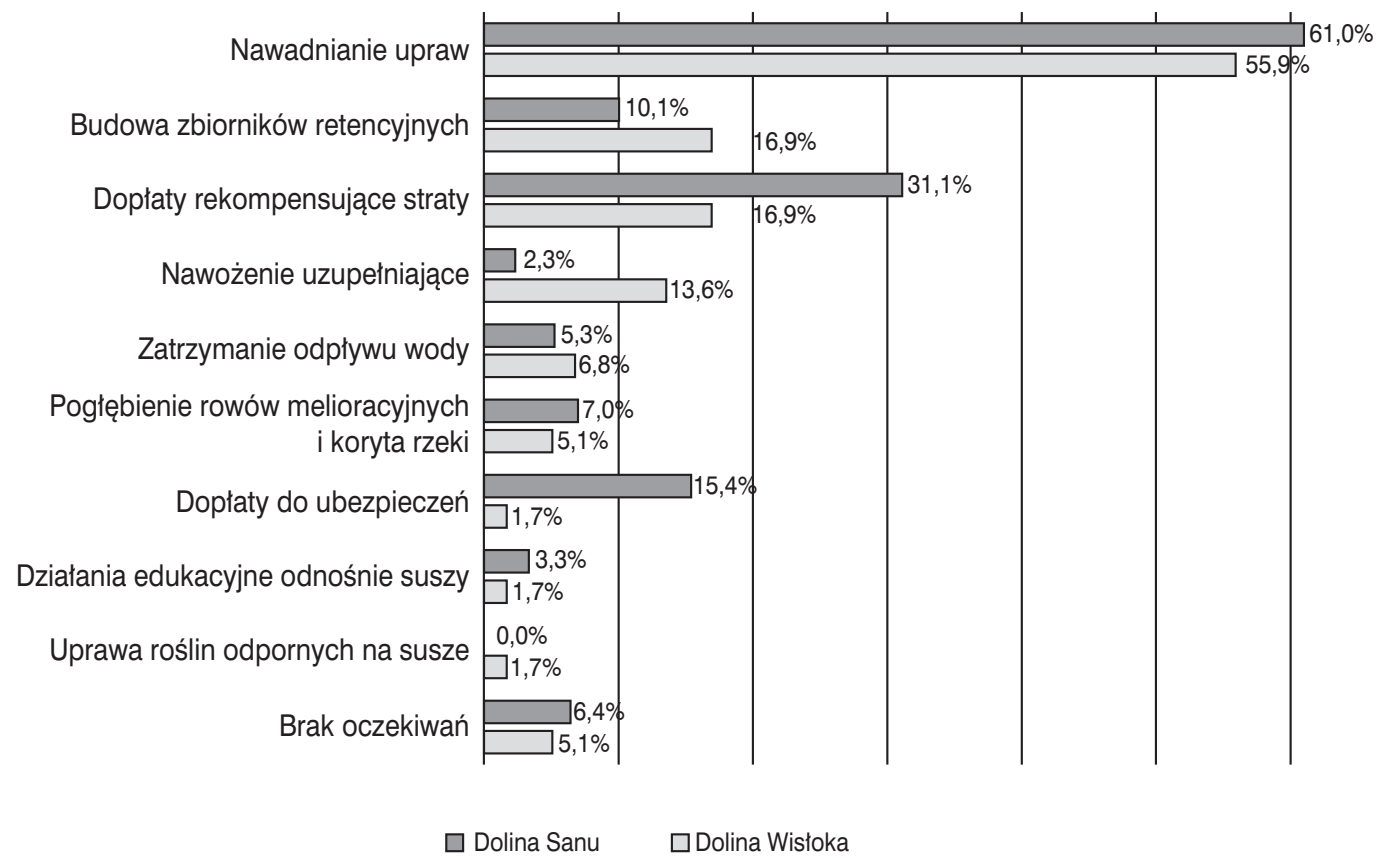

Ciekawą obserwacją był stwierdzony odsetek osób postulujących „dopłaty rekompensujące straty". Podczas wywiadu pogłębiano ten temat i wyniki wskazują, że rolnicy nie dostrzegają możliwości przeciwdziałania suszy, ponieważ jest to zjawisko, 
na które nie mają wpływu. Wydaje się natomiast, że respondenci mają niewielką wiedzę na temat małej retencji i utożsamiaja ją jedynie z małymi zbiornikami retencyjnymi. W łagodzeniu skutków suszy nie doceniano roli glebowej materii organicznej, struktury upraw, rodzaju i techniki wykonywania zabiegów agrotechnicznych oraz roli zmianowania i międzyplonów.

Czesśc wywiadu dotycząca skłonności rolników do zmiany sposobu użytkowania terenów zalewowych, polegającej na zastąpieniu upraw polowych trwałymi użytkami zielonymi, wykazała, że rolnicy gospodarujący w obu dolinach rzek, nie wyrażali takiego zamiaru. Wśród najczęściej pojawiających się motywacji do utrzymania dotychczasowego sposobu zagospodarowania był brak zapotrzebowania na pasze z TUZ oraz brak rynku zbytu na biomase łąkową. Warto podkreślić, że w projekcie polityki energetycznej do 2040 roku $^{2}$, w części dotyczącej rozwoju wykorzystania odnawialnych źródeł energii, w tym biopaliw, zwraca się uwagę na różne technologie pozyskiwania energii z biomasy, które Z powodzeniem mogą odnosić się do plonów łąk zalewowych. W prezentowanych badaniach gospodarze woleli podjąć ryzyko utraty plonów opłacalnych ekonomicznie roślin niż podjać $\mathrm{z}$ góry nieopłacalną produkcję. Niezależnie od argumentów korzyści z procesu aluwialnego na łąkach zalewowych, rolnicy upatrywali większych korzyści ekonomicznych w uprawie roślin polowych. Badani rolnicy pozytywnie przyjmowali propozycję uznania uprawy łąk łęgowych za realizację dobra publicznego, co miałoby się wiązać $\mathrm{z}$ zapewnieniem zbytu z przeznaczeniem na cele energetyczne oraz poprawą efektywności ekonomicznej TUZ.

W świetle powyższych danych odnośnie do oczekiwań społecznych, funkcji naturalnych łąk łęgowych oraz potrzeb energetycznych, należałoby opracować spójne zasady wsparcia produkcji TUZ na terenach zalewowych, w których zostaną zintegrowane cele polityki wodnej, energetycznej oraz przestrzennej z oczekiwaniami i możliwościami organizacyjnymi rolników gospodarujących na terenach zalewowych.

\section{Podsumowanie}

Zaspokajanie zapotrzebowania na energię, w tym pochodzącą ze źródeł odnawialnych, konieczność specjalnego kształto- wania przestrzeni terenów nadrzecznych w celu zapewnienia bezpieczeństwa oraz racjonalna gospodarka zasobami wodnymi znajdują wspólny mianownik w postaci energetycznego wykorzystania biomasy naturalnych łąk terenów zalewowych.

W świetle powyższych rozważań opartych na bibliografii tematu oraz przeprowadzonych badań empirycznych można postawić następujące wnioski:

- Brak specjalnego podejścia do gospodarki na terenach zalewowych nie sprzyja właściwemu wykorzystaniu ich potencjału.

- Tereny nadrzeczne mogą zostać włączone w kompleksowy system zapewniania bezpieczeństwa $\mathrm{w}$ odniesieniu do powodzi oraz suszy, dostarczając biomasy na cele zarówno paszowe, jak i energetyczne.

W konsekwencji autor, dostrzegając konieczność systemowych rozwiązań odnośnie do gospodarki na terenach zalewowych, proponuje następujące rekomendacje:

- Ograniczenie zabudowy technicznej terenów zalewowych i rozwijanie, tam, gdzie tylko jest to możliwe, uprawy półnaturalnych łąk łęgowych. Możliwość realizacji tego postulatu należy do samorządów lokalnych, które powinny utworzyć lokalne plany zagospodarowania przestrzennego uwzględniające włączenie terenów zalewowych w strategie bezpieczeństwa wodnego, polegające na uprawie trwałych użytków zielonych na terenach łęgowych.

- Wsparcie upraw celowych (TUZ) oraz rozwinięcia rynku biomasy traw łąkowych, jako realizacji dobra publicznego. Wiąże się to $\mathrm{z}$ podejściem systemowym do motywatorów zmiany zagospodarowania terenów zalewowych, stworzenia zachęt finansowych oraz animacji rynku biomasy energetycznej pozyskiwanej z łąk łęgowych. Jest to zadanie wymagające działań ustawodawczych.

- Eksploatacja technicznych zabezpieczeń przeciwpowodziowych zgodnie ze strategią pozostawiania rzekom przestrzeni, co wiąże się ze wzrostem znaczenia w zapewnianiu bezpieczeństwa, ekstensywnie użytkowanych łąk zalewowych. Postulat ten powinien zostać włączony do dokumentów strategicznych na poziomie strategii krajowych. 


\section{Przypisy}

1 Zob. Polityka Wodna Państwa do roku 2030 (z uwzględnieniem etapu do 2016) - projekt, witryna Państwowego Gospodarstwa Wody Polskie: http://www.kzgw.gov.pl/index.php/pl/ materialy-informacyjne/programy/projekt-polityki-wodnej-panstwa-do-roku-2030 (dostęp: 08.03.2019).

2 Zob. Polityka Energetyczna Polski do 2040 roku - projekt, witryna Ministerstwa Energii: https:// www.gov.pl/web/energia/polityka-energetycznapolski-do-2040-r-zapraszamy-do-konsultacji, (dostęp 08.03.2019).

\section{Bibliografia}

Alaerts, G.J. (2019). Financing for Water-Water for Financing: A Global Review of Policy and Practice, Sustainability, 11(3), 821.

Bańkowska, A., Sawa, K., Wasilewicz, M. i Żelazo, J. (2010). Analiza barier i ograniczeń w renaturyzacji rzek i dolin. W: B. Więzik (red.), Prawne, administracyjne $i$ środowiskowe uwarunkowania zagospodarowania dolin rzecznych. Bielsko-Biała: Wyd. Wyższej Szkoły Administracji.

Chapman, M., Klassen, S., Kreitzman, M., Semmelink, A., Sharp, K, Singh, G. i Chan, K.MA. (2017). 5 Key Challenges and Solutions for Governing Complex Adaptive (Food) Systems. Sustainability, 9(9), 1594.

Cherney, J.H. i Verma, V.K. (2013) Grass pellet Quality Index: A tool to evaluate suitability of grass pellets for small scale combustion systems. Applied Energy, 103, 679-684.

Ciesielczuk, T. Poluszyńska, J., Rosik-Dulewska, Cz., Sporek, M. i Lenkiewicz, M. (2016). Uses of weeds as an economical alternative to processed wood biomass and fossil fuels. Ecological Engineering, 95, 485-491.

González del Tánago, M., García de Jalón, D. i Román, M. (2012). River Restoration in Spain: Theoretical and Practical Approach in the Context of the European Water Framework Directive. Environmental Management, 50(1), 123-139.

Heinsoo, K., Melts, I., Sammul, M. i Holm, B. (2010). The potential of Estonian semi-natural grasslands for bioenergy production. Agriculture, Ecosystems and Environment, 137, 86-92.

Islam, M. i Managi, S. (2018). Sustainable Adaptation to Multiple Water Risks in Agriculture: Evidence from Bangladesh. Sustainability, 10(6).

Izydorczyk, K., Michalska-Hejduk, D., Frątczak, W., Bednarek, A., Lapińska, M., Jarosiewicz, P., Kosińska, A. i Zalewski, M. (2015). Strefy buforowe i biotechnologie ekohydrologiczne $w$ ogranicza- niu zanieczyszczeń obszarowych. Łódź: Europejskie Regionalne Centrum Ekohydrologii Polskiej Akademii Nauk.

Komunikat Komisji do Parlamentu Europejskiego, Rady, Europejskiego Komitetu Ekonomiczno-Społecznego i Komitetu Regionów. Sprawozdanie $z$ przeglądu europejskiej polityki $w$ dziedzinie niedoboru wody i susz. COM(2012) 672 final.

Kud, K. (2013). Rolnicze i ekologiczne znaczenie terenów zalewowych. Rzeszów: Oficyna Wydawnicza Politechniki Rzeszowskiej.

Kud, K. (2016). Zarządzanie gospodarką rolną na terenach zalewowych w kontekście globalnych zmian klimatycznych. Zesz. Nauk. SGGW w Warszawie, Problemy Rolnictwa Światowego, 16(XXXI), z. 3, 221-231.

Kud, K. (2017). Małe gospodarstwa rolne jako ekoinnowacyjny element rozwoju zrównoważonego obszarów nadrzecznych, Prace Naukowe UE we Wroctawiu, 491, 264-272.

Kud, K. i Kud, B. (2012). Space for the river as a part of flood losses reducings, Proceedings of the Green Economics Institute 7th Annual Green Economics Conference. Oxford: Green Economics Institute.

Kundzewicz, Z.W. (2011). Zmiany klimatu, ich przyczyny i skutki - obserwacje i projekcje. Landform Analysis, 15, 39-49.

Lechowska, E. (2017). Zrównoważony rozwój (zagospodarowanie) obszarów zalewowych jako kluczowy element ochrony terenów zurbanizowanych. Rozwój Regionalny i Polityka Regionalna, 38, 109-120.

Lorenc, H. (red.) (2012). Klęski żywiołowe a bezpieczeństwo wewnętrzne kraju. Seria Monografie $I M G W-P I B$. Warszawa

Melts, I., Heinsoo, K., Nurk, L., Pärn L. (2013). Comparison of two different bioenergy production options from late harvested biomass of Estonian semi-natural grasslands. Energy 61, 6-12.

NIK (2017). Informacja o wynikach kontroli System gospodarowania przestrzenia gminy jako dobrem publicznym, nr ewid. 193/2016/KIN.

Polityka Energetyczna Polski do 2040 roku - projekt, witryna Ministerstwa Energii: https://www. gov.pl/web/energia/polityka-energetyczna-polskido-2040-r-zapraszamy-do-konsultacji (dostęp: 08.03.2019).

Polityka Wodna Państwa do roku 2030 (z uwzględnieniem etapu do 2016) - projekt, witryna Państwowego Gospodarstwa Wody Polskie: http://www. kzgw.gov.pl/index.php/pl/materialy-informacyjne/ programy/projekt-polityki-wodnej-panstwa-doroku-2030 (dostęp: 08.03.2019).

Schuch, G., Serrao-Neumann, S., Morgan, E. i Low Choy, D. (2017). Water in the city: Green open 
spaces, land use planning and flood management - An Australian case study. Land Use Policy, 63, 539-550.

Twaróg, B. (2014). Ochrona przeciwpowodziowa versus optymalna ochrona przeciwpowodziowa, czyli subiektywizm działań optymalnych. Gospodarka Wodna, 5, 173-179.

Ustawą o planowaniu i zagospodarowaniu przestrzennym, Dz.U. 2017 poz. 1073.

Watson, K.B., Ricketts, T., Galford, G., Polasky, S. i O’Niel-Dunne, J. (2016). Quantifying floodmitigation services: The economic value of Otter Creek wetlands and floodplains to Middlebury, VT. Ecological Economics, 130, 16-24.
Wehn, U., Rusca, M. i Evers, J. (2015). Participation in flood risk management and the potential of citizen observatories: A governance analysis. Environmental Science \& Policy, 48, 225-236.

Westhoek, H.J., Overmars, K.P. i van Zeijts, H. (2013). The provision of public goods by agriculture: Critical questions for effective and efficient policy making. Environmental Science \& Policy, 32, 5-13.

Woźniak, L. i Kud, K. (2006). Economic and ecological importance of the alluviation process in agriculture - fresh alluvial sediments as a source of nutrient elements for plants. Agrochemistry Scientific Journal for Rational Utilization of Agrochemicals in Agriculture. V. X., 46(3), 23-26. 